\title{
Quality of Employment in Small and Medium Enterprises in Romania
}

\author{
Daniela PASNICU* \\ Ghenadie CIOBANU**
}

\begin{abstract}
In this article we propose to discuss the quality of employment in SMEs in Romania. We have debated the role of small and medium-sized enterprises in the Romanian economy, public policy proposals to create an ecosystem that promotes transformation of structure, resilience and development in SMEs, the presentation of the situation of the SME sector at the regional level, the evolution of the innovation typology, 2010-2012, the major difficulties faced by SMEs. In order to have an overview and to answer a series of questions about the quality of occupation in the Romanian $S M E s$, and their perspective, we have performed a radiography of some works from the field of international experience.
\end{abstract}

Keywords: Quality, employment, enterprises, industry

JEL classification: M10, M12, M14

DOI: $10.24818 / \mathrm{RMCl} .2018 .1 .64$

\section{Introduction}

In the 2020 Strategy, the flagship initiative "An industrial policy geared to the globalization era" it's said : "Industry and SMEs in particular have been severely affected by the economic crisis and all sectors are facing the general challenges of globalization and adapting their production processes and products to a low-carbon economy. "1

Given the diversification of the challenges, some sectors will be radically restructured; for other sectors new business opportunities are emerging as a result of these challenges. In the field of SME development, the European Commission aims to contribute to the improvement of the business environment, especially for SMEs, by reducing transaction costs related to the conduct of an economic activity in Europe, by promoting clusters, and improving convenient access to finance; by promoting the internationalization of SMEs, and at national level, Member States will have to improve the business environment, in particular for innovative SMEs,

* Daniela Pasnicu, National Institute of Scientific Research in Labor and Social Protection

** Ghenadie Ciobanu, National Institute of Scientific Research in Labor and Social Protection

${ }^{1}$ Strategia 2020, O strategie europeană pentru o creștere inteligentă, ecologică şi favorabilă incluziunii, Comisia Europeană, Bruxelles, 3.3.2010 COM(2010) 2020 final, p. 20 https://www.mae.ro/sites /default/files/file/Europa2021/Strategia_Europa_2020.pdf 
including through public procurement aimed at supporting innovation-friendly initiatives.

Under the 2014-2020 Nationale for Competitiveness Strategy ${ }^{2}$, modern industrial activity depends on multiplying inter and intra-industry cooperation between large firms and SMEs, especially by attracting them into research or experimentation activities of multinational firms. The multiplication of this cooperation, although desirable because it would have beneficial effects for SMEs, will only develop if, in advance, SMEs will achieve their "critical mass" in terms of quality, costs, and developmental strength and will thus enter the value chain of higher-ranking suppliers.

The strategy identifies the dependence between competitiveness and societal challenges as part of any solution for the next period of development. At the institutional level, through the Priority of the Regulatory, Sectoral Environment, through the Priority of Promoting the 10 sectors of the future, and at the level of the entire society, through Priority 2050 Generation Prepared, convergent measures are needed to form a strong social cohesion and turn it into a source of sustainable competitive advantage.

From the Study on "SME contribution to growth - present and prospects" 3 in public policy proposals to create an ecosystem conducive to structural change, resilience and development in the SME sector: "The first component of public policy must address the entrepreneurial development issue much more strongly and more coordinated, starting from the fact that the density of Romanian entrepreneurs versus the population is much lower than the average of the developed countries. The second component of public policy is dimensional, which implies that the priority target of public support is small-sized SMEs, or even micro-enterprises. The third component addresses the sectoral profile of SMEs. The current analysis suggests that the share of SMEs active in trade / intermediation and construction is too high compared to other developed countries.

The fourth component is based on the fact that new businesses are being created in Romania, but their survival rate is very low. "Therefore, in addition to incentives for the creation of new firms (eg, the recent measure of encouraging young business start-ups), steps need to be taken to assist and guide newly created firms in order to extend their life span.

"The role of small and medium enterprises in the Romanian economy" ${ }^{4}$. As regards the SME sector, the main law currently governing measures to create a favorable framework for the establishment and development of these enterprises is Law No.346 of 14 July $2004^{5}$. According to her: "the enterprise is any form of

2 Strategia Națională pentru competitivitate 2014-2020 http://www.minind.ro/PROPUNERI_ LEGISLATIVE/2014/SNC_2014_2020.pdf

3 *** Studiu, Contribuția IMM-urilor la creșterea economică - prezent șiperspective, Proiect Îmbunătăţirea capacităţii instituţionale, de evaluare şi formulare de politici macroeconomice în domeniul convergenţei economice cu Uniunea Europeană a Comisiei Naţionale de Prognoză, http://www.cnp.ro/inovatie/docs/seminar-studii-25-06-2012/Rezumat\%20studiu\%20IMM.pdf

${ }^{4}$ The role of small and medium enterprises in the Romanian economy

${ }^{5}$ Law No.346 of 14 July 2004 
organization of an economic activity, self-owned patrimonial and authorized according to the legislation in force to do acts and deeds of commerce for the purpose of obtaining profit, under competitive conditions. Businesses can be: commercial companies, cooperative societies, independent individuals and family associations, all authorized under the laws in force.

In the economic reality, there are two types of SMEs: the small traditional enterprise (which, as a rule, does not have a long-term strategy, has a limited market, and technologies are being passed on from generation to generation) and modern SMEs (using cutting-edge technologies, they are continually searching for new markets and, through competence, aim to maximize the efficiency of their business).

Share of the turnover achieved by small and medium-sized active enterprises in the turnover of enterprises in industry, construction, commerce and other services, by activities of the national economy.

Table 1. ${ }^{6}($ percent - \% - )

\begin{tabular}{|l|c|c|c|}
\hline Activity (CANE Rev.2 sections) & $\mathbf{2 0 1 1}$ & $\mathbf{2 0 1 2}$ & $\mathbf{2 0 1 3}$ \\
\hline Total & $\mathbf{5 8 , 2}$ & $\mathbf{5 7 , 9}$ & $\mathbf{5 8 , 0}$ \\
\hline & & & \\
\hline Extractive industry & 10,4 & 9,5 & 10,5 \\
\hline Manufacturing industry & 37,4 & 36,3 & 35,8 \\
\hline $\begin{array}{l}\text { Production and supply of electricity and heating, gas, hot } \\
\text { water and conditioning }\end{array}$ & 28,5 & 32,6 & 31,5 \\
\hline $\begin{array}{l}\text { Water distribution, sanitation, management waste, } \\
\text { decontamination activities }\end{array}$ & 68,9 & 69,6 & 66,4 \\
\hline Construction & 75,7 & 77,5 & 80,7 \\
\hline $\begin{array}{l}\text { Wholesale and retail trade; repair motor vehicles and } \\
\text { motorcycles }\end{array}$ & 71,2 & 69,9 & 71,3 \\
\hline Transport and storage & 65,6 & 66,3 & 68,5 \\
\hline Hotels and restaurants & 84,6 & 85,2 & 84,0 \\
\hline Information and communications & 42,6 & 43,9 & 43,3 \\
\hline Professional, scientific and technical activities & 87,5 & 86,9 & 84,9 \\
\hline $\begin{array}{l}\text { Activities and administrative services and activities support } \\
\text { services }\end{array}$ & 76,5 & 77,1 & 74,6 \\
\hline Education & 95,1 & 94,3 & 93,6 \\
\hline Health and social assistance & 74,4 & 74,5 & 71,8 \\
\hline Performing, cultural and recreational activities & 67,9 & 70,3 & 68,5 \\
\hline Other service activities & 97,0 & 97,1 & 97,1 \\
\hline
\end{tabular}

Source: National Institute of Statistics

\footnotetext{
${ }^{6}$ Institutul Național de Statistică, http://www.insse.ro/cms/files/publicatii/pliante\%20statistice/IMM2014.pdf
} 
Share of the turnover of small and medium-sized active enterprises in the turnover of enterprises in industry, construction, commerce and other services, by activities of the national economy. According to statistical information the situation is the following Industry of SMEs at regional level

In Table 1, below, we present the evolution of the SME industry.

Table 2. Evolution of the SME sector in INDUSTRY by regions

\begin{tabular}{|l|c|c|c|c|c|}
\hline & $\mathbf{2 0 1 2}$ & $\mathbf{2 0 1 3}$ & & $\mathbf{2 0 1 4}$ \\
\hline Number of local units, Total & 52101 & & 53167 & & 54812 \\
\hline Macro-region one & $\mathbf{1 6 3 3 4}$ & & $\mathbf{1 6 6 7 7}$ & & $\mathbf{1 7 2 2 6}$ \\
\hline Northwest & 8430 & & 8696 & & 9077 \\
\hline Center & 7904 & & 7981 & & 8149 \\
\hline Macro-region two & $\mathbf{1 2 4 6 1}$ & & $\mathbf{1 2 6 2 2}$ & & $\mathbf{1 2 9 1 8}$ \\
\hline North - East & 6532 & & 6539 & & 6690 \\
\hline South East & 5929 & & 6083 & & 6228 \\
\hline Macro-region three & $\mathbf{1 4 2 1 4}$ & & $\mathbf{1 4 5 9 8}$ & & $\mathbf{1 5 2 1 1}$ \\
\hline South-Muntenia & 5832 & & 6000 & & 6182 \\
\hline Bucharest-Ilfov & 8382 & & 8598 & & 9029 \\
\hline Macroregion four & $\mathbf{9 0 9 2}$ & & $\mathbf{9 2 7 0}$ & & $\mathbf{9 4 5 7}$ \\
\hline South-West Oltenia & 3892 & & 3942 & & 4007 \\
\hline West & 5200 & & 5328 & & 5450 \\
\hline Source: INS & & & & \\
\hline
\end{tabular}

Northwest Region 9077 SME, 8149 Center, From the macro-region 2 with 12918 SMEs, North-East Region with 6690 SMEs, South-East with 6228, South Muntenia Region with 6182 SMEs, Bucharest-Ilfov with 9029 SMEs. The smallest number of enterprises register the Macroregion four, South-West Oltenia - 4007, West 5450 enterprises. Table 3 shows the number of persons employed in industrial SMEs by region.

Table 3. Number of persons employed in industrial SMEs by region

\begin{tabular}{|l|c|c|c|c|c|}
\hline & $\mathbf{2 0 1 2}$ & & $\mathbf{2 0 1 3}$ & \multicolumn{2}{|c|}{$\mathbf{2 0 1 4}$} \\
\hline Number of people employed, Total & $\mathbf{7 5 8 9 2 9}$ & & $\mathbf{7 5 3 0 8 4}$ & \multicolumn{2}{|c|}{$\mathbf{7 4 1 2 3 3}$} \\
\hline Macro-region one & $\mathbf{2 4 6 3 3 6}$ & & $\mathbf{2 4 5 8 1 7}$ & & $\mathbf{2 4 5 8 4 1}$ \\
\hline Northwest & 119592 & & 121776 & & 122989 \\
\hline Center & 126744 & & 124041 & & 122852 \\
\hline Macro-region two & $\mathbf{1 7 5 4 4 7}$ & $\mathbf{1 7 1 5 0 7}$ & & $\mathbf{1 6 7 4 8 0}$ \\
\hline North - East & 88562 & & 87404 & 85012 \\
\hline South East & 86885 & & 84103 & 82468 \\
\hline
\end{tabular}




\begin{tabular}{|l|c|c|c|c|c|}
\hline & $\mathbf{2 0 1 2}$ & $\mathbf{2 0 1 3}$ & $\mathbf{2 0 1 4}$ \\
\hline Macro-region three & $\mathbf{1 9 9 9 6 4}$ & $\mathbf{2 0 1 3 1 8}$ & & $\mathbf{1 9 6 9 5 8}$ \\
\hline South-Muntenia & 100799 & & 102715 & 100265 \\
\hline Bucharest-Ilfov & 99165 & & 98603 & & 96693 \\
\hline Macroregion four & $\mathbf{1 3 7} \mathbf{1 8 2}$ & & $\mathbf{1 3 4} \mathbf{4 4 2}$ & $\mathbf{1 3 0 9 5 4}$ \\
\hline South-West Oltenia & 53694 & 52679 & 51819 \\
\hline West & 83488 & 81763 & 79135 \\
\hline Source: p.14 & & & \\
\hline
\end{tabular}

Regarding the innovation typology issue, during 2010-2012 the situation evolved in the following way ....

Table 4. Typology of innovations during 2010-2012

\begin{tabular}{|c|c|c|c|c|}
\hline & & $\begin{array}{c}\text { Total number } \\
\text { businesses }\end{array}$ & $\begin{array}{c}\text { Number business } \\
\text { innovative }\end{array}$ & $\begin{array}{c}\text { Front weight of } \\
\text { total business }\end{array}$ \\
\hline \multicolumn{2}{|c|}{ Total } & 28866 & 5968 & 20,7 \\
\hline \multirow[t]{2}{*}{ of which } & Small & 22400 & 4089 & 18,3 \\
\hline & Medium & 5270 & 1400 & 26,6 \\
\hline \multicolumn{2}{|c|}{ Industry } & 15210 & 3415 & 22,5 \\
\hline \multirow[t]{2}{*}{ of which } & Small & 10892 & 2217 & 20,4 \\
\hline & Medium & 3429 & 843 & 24,6 \\
\hline \multicolumn{2}{|c|}{ Extractive industry } & 321 & 45 & 14,0 \\
\hline \multicolumn{2}{|c|}{ Manufacturing } & 13894 & 3200 & 23,0 \\
\hline \multirow[t]{2}{*}{ of which } & Small & 9998 & 2110 & 21,1 \\
\hline & Medium & 3143 & 786 & 25,0 \\
\hline \multicolumn{2}{|c|}{ Services } & 13656 & 2553 & 18,7 \\
\hline \multirow[t]{2}{*}{ of which } & Small & 11508 & 1872 & 16,3 \\
\hline & Medium & 1841 & 557 & 30,3 \\
\hline
\end{tabular}

Source: SMEs Small and Medium Enterprises in Figures, Romania National Institute of Statistics, Bucharest 2015

Developing the creative and innovative potential of young people through non-formal learning in ways that are relevant to employability, Expert Group Report ${ }^{7}$.

\section{Major difficulties faced by SMEs}

\footnotetext{
${ }^{7}$ http://ec.europa.eu/assets/eac/youth/news/2014/documents/report-creative-potential_en.pdf 
From research conducted in the White Paper on SMEs in Romania, 13th Edition $^{8}$.

Table 5. The frequency of major difficulties faced by SMEs

\begin{tabular}{|c|c|c|c|c|c|c|c|}
\hline & & 2009 & 2010 & 2012 & 2013 & 2015 & 2016 \\
\hline 1 & Decline in domestic demand & 66.20 & 67.77 & 60.55 & 70.08 & 59.49 & 36.31 \\
\hline 2 & Bureaucracy & 47.07 & 41.39 & 52.86 & 36.11 & 55.27 & 61.41 \\
\hline 3 & Excessive taxation & 54.61 & 48.44 & 51.69 & 54.25 & 54.47 & 54.74 \\
\hline 4 & Inflation & 30.51 & 44.40 & 49.59 & 50.27 & 46.69 & 21.90 \\
\hline 5 & Corruption & 25.86 & 36.10 & 41.14 & 30.95 & 37.38 & 45.16 \\
\hline 6 & Excessive controls & 18,11 & & 40.56 & 41.50 & 45.16 & 44.98 \\
\hline 7 & $\begin{array}{l}\text { Hiring, training and } \\
\text { maintaining staff }\end{array}$ & 18.25 & 22.91 & 24.94 & 28.53 & 19.13 & 26.37 \\
\hline 8 & $\begin{array}{l}\text { Competition of imported } \\
\text { products }\end{array}$ & 19,06 & 14.38 & 22.90 & 16.95 & 19.20 & 19.71 \\
\hline 9 & Difficult access to credit & 26.13 & & 20.22 & 14.59 & 21.89 & 12,50 \\
\hline 10 & High credit costs & 36.09 & 27.80 & 19.17 & 16.58 & 13.89 & 15.24 \\
\hline 11 & $\begin{array}{l}\text { Relative instability of the } \\
\text { national currency }\end{array}$ & 26.80 & 21.15 & 19.00 & 17.81 & 16.36 & 13.14 \\
\hline 12 & $\begin{array}{l}\text { Delays in collecting invoices } \\
\text { from private companies }\end{array}$ & 36.70 & 27.52 & 15.79 & 12,92 & 12,44 & 19.62 \\
\hline 13 & Increase in wage bill & 20.34 & 19.56 & 9,62 & 25.46 & 14.25 & 24.54 \\
\hline 14 & $\begin{array}{l}\text { Non-payment of bills by state } \\
\text { institutions }\end{array}$ & 15.35 & 13.47 & 7,40 & 5,49 & 5,67 & 11,41 \\
\hline 15 & Decline in export demand & 6,94 & 5,06 & 7,17 & 5,54 & 6,11 & 10,04 \\
\hline 16 & $\begin{array}{l}\text { Getting the firm's advice and } \\
\text { training }\end{array}$ & 3,50 & 4, 09 & 5,24 & 5,87 & 6,18 & 8,58 \\
\hline 17 & Poor infrastructure quality & 12,32 & 15.86 & 4,90 & 12,00 & 15.13 & 18.16 \\
\hline 18 & $\begin{array}{l}\text { Knowledge and adoption of } \\
\text { the acquis communautaire }\end{array}$ & 2,90 & 1,82 & 2,27 & 3,44 & 4,22 & 4,65 \\
\hline 19 & Other & 1,35 & 0.97 & 0.93 & 0,59 & 0.87 & 0.27 \\
\hline 20 & Unfair competition & & & & 38.11 & $\mathbf{3 7 . 2 5}$ & 40.33 \\
\hline
\end{tabular}

Source: Table developed by the author on the basis of the White Paper Research Reports of SMEs for 2009-2011, 2015-16

From this analysis we highlight several interesting situations: Domestic demand decrease from 66.20 to 36.31 ; Increasing bureaucracy from 47.07 to 61.41 , the tax rate remains practically unchanged from 54.61 in 2009 to 54.74 in 2016, although in 2010 it had a good result of 48.44, inflation from 30.51 to 21.90 .

${ }^{8}$ White Paper on SMEs in Romania, 13th Edition, Carta Albă a IMM-urilor din România 2015, Bucureşti, iunie 2015 , Ediția a XIII-a 
Corruption is rising from 25.86 to 45.16 , although excessive controls have increased from 18.11 in 2009 to 44.98 in 2016.

In our study, we highlighted an important analysis for us, "from the point of view of the studies, most entrepreneurs have higher education (63.96\%), and 5.93\% graduated from the master, $3.38 \%$ followed various postgraduate studies and $0.82 \%$ doctoral students.

"The authors are of the opinion that" the situation shows us a high degree of intellectualisation of entrepreneurs, which is a favorable phenomenon for enhancing the performances of SMEs in the next period and for the transition to the knowledgebased economy". ${ }^{9}$ The grouping of entrepreneurs according to the training programs followed shows that $2.10 \%$ of them trained in Romania and $1.19 \%$ participated in training programs abroad.

In order to be able to have an overview and to answer a number of questions regarding the quality of employment in the Romanian SMEs, and their perspective, we have performed a radiography of some works in the field from international experience.

In the paper "Quality of Employment and Employment Relations in Europe $^{10}$, the following issues are addressed: (1) Conceptual framework and objectives; (2) Distribution of employment quality indicators in Europe; (3) The individual and country-quality attributes of quality employment; (4) Typology of jobs based on job quality. The study provides an in-depth analysis of the quality of working conditions and labor relations in the workforce at European level. Employment in the work is regarded as the contractual relationship between an employer and an employee, in particular how the rights and obligations embodied in the relationship are translated into real rights.

The main objectives of the study are: (1) Building indicators for different dimensions of job quality; (2) identification of problematic or advantageous situations in terms of job quality, as well as groups of workers (employees) requiring special attention; (3) examining the evolution of a number of indicators selected for the quality of employment; (4) investigating the relationship between job quality and a set of characteristics of individual workers, employers' organizations, broader job characteristics, and variations across countries. Another work, Osabiya Babatunde, Ikenga Emem, examines the impact of leadership on employee performance in an organization. The authors showed: "The impact of leadership on employee performance in an organization, Establishing the relationship between employee performance and productivity, which is the hallmark of the organization's goals. The study showed that there is a significant relationship between leadership style and employee performance in achieving the goals and objectives of the organization."11

9 p. 24

${ }^{10}$ Cornell University ILR School DigitalCommons@ILR, European Foundation for the Improvement of Living and Working Conditions, 2013 http://digitalcommons.ilr.cornell.edu/cgi/viewcontent. cgi? article $=1333 \&$ context $=$ intl

11 Public Policy and Administration Research www.iiste.org, ISSN 2224-5731(Paper) ISSN 22250972(Online), Vol.5, No.1, 2015 
The paper is designed to study the impact of leadership on employee performance in an organization. For each organization to achieve its objectives, there must be a strong relationship between leaders and employees. For productivity to be a reality in an organization, there must be high performance of employees who depend only on leadership style. The human being joins organizations voluntarily in normal circumstances because of personal needs and aspirations, not necessarily for organizational purposes. A leader tries to motivate his workers to work better in an organization, while helping to achieve personal aspirations. To increase the performance of an employee, workers will depend on a particular leadership style that works within the organizational framework. No leader uses style exclusively. A leader can use an autocratic style when needed to serve a special purpose and democratic style in the other case.

The authors are of the opinion that: "Effective leadership and management are widely recognized as a key priority for national and regional development, the process through which they are improved through training and development, how they influence performance remain poorly understood. There is a lack of reliable data to link the development of management and leadership with leadership and individual and organizational performance, and the evidence "suggests a more complex relationship between them" than is often supposed. "

The authors Carmine Bianchi, Milica Marinković, Federico Cosenz, in the study „A Dynamic Performance Management Approach to Evaluate and Support SMEs Competitiveness: Evidences from a Case Study" have approached: "The role of performance management systems (PM) has become essential to make small and medium-sized enterprises (SMEs) compete successfully during the transition of the critical economy." 12

The authors believe that in order to improve the strategic learning processes of the decision makers, it is necessary to combine the traditional performance management frameworks with the Dynamic System modeling. In the study, they presented how to design and use a dynamic performance management approach (DPM) to assess and support the competitiveness of SMEs. The emerging framework is applied to a real case of a small business to analyze the empirical effectiveness of the suggested approach. The long-term survival of SMEs on the market depends mainly on the results they can achieve in terms of competitiveness, profitability and ability to meet social demands. Therefore, there was a need to improve the performance of SMEs on the basis of sustainable competitive strategies.

SMEs may need a tailored approach to enable key actors to shape their own dynamic complexity (ie entrepreneurship actors and their direct collaborators) and understand how to pursue sustainable development, time and space compromises, and evaluate the results of implementing the strategy. In the opinion of the authors

12 Carmine Bianchi, Milica Marinković , Federico Cosenz, A Dynamic Performance Management Approach to Evaluate and Support SMEs Competitiveness: Evidences from a Case Study http://www.systemdynamics.org/conferences/2013/proceed/papers/P1225.pdf 
Christine Erhel and Mathilde Guergoat-Lariviere, ${ }^{13}$ in the work "Job quality and labor market performance": "Job quality is a multidimensional concept that can be defined using four main dimensions and measured by indicators such as the socalled" Laeken ". The empirical analysis of quality in Europe leads to three main types of results. Firstly, it reveals significant differences between countries, with four prevalent prevailing regimes in Europe. Secondly, it supports the assumption that a higher level of quality is associated with better performance of the labor market and economic performance. Finally, it highlights the heterogeneity of quality in social groups, especially by gender, age and education. "The authors ask the question:" How do you define the quality of jobs?

"It is trying to answer:" In the labor market, the quality of jobs is related to working conditions. Recent developments in the economy and socio-economic approaches propose additional dimensions for defining job quality. Developments in human capital theory recognize the heterogeneity of both jobs and workers as well as a step that can be taken to differentiate job quality according to the skills involved, in particular, job or qualification mismatch between workers and jobs. At macro level, market failures can be seen as an indicator of the quality of employment. "

In the article "The main trends in the development of worker quality", the author G.T. Kalmanbetova, ${ }^{14}$ analyzes the qualitative characteristics of the workforce, as well as the need for modernization, taking into account the global development trends in this area. In today's world, a new type of economic growth has begun to develop in developed countries, which has been called innovation, the essence of which is that on the scientific basis of development time, new products and services are designed and manufactured in all areas of society. This means that in the modern world a decisive factor for economic growth is influenced by "new knowledge and modern technology".

The results of these activities are diverse, in particular: First, they lead to the erosion of production through the development and implementation of complex technologies; Secondly, they form the situation when it becomes necessary to prepare for an adequate quality of workforce able to serve these innovative technologies and new equipment. The above means that at the present stage it is necessary to balance, that is, identifying the matching of the nature of the workforce and the level of development of the means of production. The close relationship of labor and means of production becomes more evident on the basis of accelerated technological progress, which spreads across the entire sphere of the productive forces of society. And the development of new scientific and technological research

${ }^{13}$ CEPS Working Document No. 330/June 2010, CEPS Working Documents are intended to give an indication of work being conducted within CEPS research programmes and to stimulate reactions from other experts in the field. Unless otherwise indicated, the views expressed are attributable only to the authors in a personal capacity and not to any institution with which they are associated. ISBN 978-94-6138-036-4

Available for free downloading from the CEPS website (http://www.ceps.eu),Centre for European Policy Studies, 2010

14 Г.T. Калманбетова ОСНОВНЫЕ ТЕНДЕНЦИИ В РАЗВИТИИ КАЧЕСТВА РАБОЧЕЙ СИЛЫ, Вестник КРСУ. 2014. Том 14. № 3, pp. 151-154 
makes an essential shift in labor rights, and has gradually reduced the scope of unskilled workforce.

In the paper „Pennsylvania's Best Investment: The Social and Economic Benefits of Public Education" 15 the authors Mitra D consider: Research shows that people who graduate from an institution and have access to quality education during primary and secondary education are more likely to find paid jobs, have stable families and be active and productive citizens. They are less likely to commit serious crimes, less likely to make high demands for the public health system, and less likely to be enrolled in social assistance programs. " Good education offers substantial benefits to individuals, as individual benefits are aggregated within a community, create broad social and economic benefits. Investing in public education is more cost-effective for the state than paying for the social and economic consequences of poorly funded schools. The "national research" reviewed in this paper has developed over the years to document the social and economic impact of public education. Researchers in this area have focused on a national perspective, using data from communities and school systems across the country. The authors believe that much further research is needed on the social and economic impact of public education. In conclusion of this study, the author is of the opinion: " Resources invested in improving the quality of education should be seen more than current spending on schools and students attending them."

Such expenditures are long-term investments in strong families, a strong workforce and strong communities. Education serves an important role in accessing the information and skills needed by individuals to participate in higher education to support a place productive work and making effective choices in crime, healthcare and civic participation. "

Author Jonas Onkelinx in the study "The role of employee human capital in the accelerated internationalization of SMEs: empirical evidence from Belgium," 16 Analyzes the role of general and specific human capital to accelerate the internationalization of small and medium-sized enterprises (SMEs) in the context of Belgium. The author studies an innovation-based economy. More specifically, it analyzes the effect of employee education (General Human Capital) and training (specific human capital) and suggests a threshold after which additional firm investment in human capital becomes less productive. Test ideas using a single set of data for all SMEs in Belgium that were internationalized in 1998 and 2005 and followed an accelerated internationalization strategy $(n=2633)$. The findings indicate a significant (U inverse) association between general human capital (education) and the degree of internationalization of the company, while it is a

\footnotetext{
${ }^{15}$ Mitra D., Pennsylvania's Best Investment: The Social and Economic Benefits of Public Education https://www.elc-pa.org/wp-content/uploads/2011/06/BestInvestment_Full_Report_6.27.11.pdf

${ }^{16}$ Jonas Onkelinx, Tatiana S. Manolova, Linda F. Edelman, The Role of Employee Human Capital in the Accelerated Internationalization of SMEs: Empirical Evidence from Belgium, Frontiers oolef Entrepreneurship Research, Volume 32| Issue 16, Chapter XVI. INTERNATIONAL, Article 1, 6-92012
} 
specific human capital (in training). It is not significantly associated with the degree of internationalization, theoretical and practical implications are discussed.

The authors Christine Erhel and Mathilde Guergoat-Lariviere, in the study "Job quality and labor market performance", have shown: "The quality of jobs as a multidimensional concept, which can be defined using four main dimensions and measured by indicators such as the so-called" Laeken". ${ }^{17}$ The empirical analysis of quality in Europe leads to three main types of results. Firstly, it reveals significant differences between countries, with four prevalent prevailing regimes in Europe.

Secondly, it supports the assumption that a higher level of quality is associated with better performance of the labor market and economic performance. Finally, it highlights the heterogeneity of quality in social groups, especially by gender, age and education.

\section{Conclusion}

(1) The creation of high-quality jobs is an important condition for maintaining a sustainable working career, motivating workers and labor productivity, as well as to minimize incapacity for work and accidents and to improve professional health.

In order to design an SME management system, we must take into account the following moments specific to the SME activity in Romania:

(2) Effective management management is a priority for national and regional development, the methodology by which they are improved through training and development, how they influence performance remain low.

(3) The lack of information needed to link the development of management and leadership with leadership and individual and organizational performance suggests creating a complex relationship between them.

(4) Understanding the relationship between leaders and their constituents is essential. Developing and maintaining successful organizations requires leaders to understand the culture of the organization in order to adapt to the challenges of the environment and to respect the constituent constituents of the organization.

(5) Management's responsibility extends from executive officers and beyond "local levels of the public. Leaders' capabilities and limitations must be understood so that workers can intelligently strengthen and support" good "leadership.

(6) For efficient employee performance, the organization should adopt an effective leadership style.

(7) The organization must formulate policies that encourage leaders to empower employees to participate in the organization.

\footnotetext{
${ }^{17}$ CEPS Working Documents are intended to give an indication of work being conducted within CEPS research programmes and to stimulate reactions from other experts in the field. Unless otherwise indicated, the views expressed are attributable only to the authors in a personal capacity and not to any institution with which they are associated. ISBN 978-94-6138-036-4

Available for free downloading from the CEPS website (http://www.ceps.eu) C Centre for European Policy Studies, CEPS Working Document No. 330/June 2010
} 
(8) Leadership that encourages the principle of quality to be implemented by the authority. Leaders, who can delegate authority with employee confidence, are a response to productivity issues.

(9) The achievement of the management objective depends on the satisfaction of the employees. A leader should act in the historical context and the environment.

(10) Education plays an extremely important role in providing access to the information and skills needed by individuals to participate in higher education in support of productive work.

(11) Quality schools produce strong individuals and thus help families and communities remain strong. Unlike schools facing difficulties, they are often associated with communities in difficulty and high levels of unemployment, crime, illness and social alienation. Low-wealth communities lack the resources to support quality schools themselves, creating a socially and economically disadvantaged cycle of disruption without investment and technical assistance from the state.

\section{References}

1. Christine Erhel and Mathilde Guergoat-Larivière, Job quality and labour market performance, CEPS Working Document No. 330/June 2010, ,CEPS Working Documents are intended to give an indication of work being conducted within CEPS research programmes and to stimulate reactions from other experts in the field. Unless otherwise indicated, the views expressed are attributable only to the authors in a personal capacity and not to any institution with which they are associated. ISBN 978-94-6138-036-4, Available for free downloading from the CEPS website (http://www.ceps.eu) (C) Centre for European Policy Studies, 2010

2. Carmine Bianchi, Milica Marinković, Federico Cosenz, A Dynamic Performance Management Approach to Evaluate and Support SMEs Competitiveness: Evidences from a Case Study

3. Faruk Ahmeti, PhD, Bekim Marmullaku, MSc, Human resource management and practices in smes in developing countries: practices in Kosovo, European Scientific Journal March 2015 edition vol.11, No.7 ISSN: 1857-7881 (Print) e-ISSN 1857-7431

4. Employment and quality of employment in Vietnam: The roles of small firms, formalization and education, Nguyen Tu Anh, Nguyen Thu Thuy, Dang Thi Thu Hoai, Swiss Programme for Research on Global Issues for Development, R4D Working Paper 2015/8, http://www.r4d-employment.com/wpcontent/uploads/2016/08/Employment-and-Quality-of-Employment.pdf

5. G.T. Kalmanbetova, The main trends in development of worker quality, Г.T. Калманбетова ОСНОВНЫЕ ТЕНДЕНЦИИ В РАЗВИТИИ КАЧЕСТВА РАБОЧЕЙ СИЛЫ, Вестник КРСУ. 2014. Том 14. № 3, pp. 151-154 
6. Jan de Kok, Paul Vroonhof, Wim Verhoeven, Niek Timmermans, Ton Kwaak, Jacqueline Snijders Florieke Westhof, Zoetermeer, November 2011

7. Jonas Onkelinx, Tatiana S. Manolova, Linda F. Edelman, The role of employee human capital in the accelerated internationalization of smes: empirical evidence from belgium , Frontiers of Entrepreneurship Research, Volume $32 \mid$ Issue 16, Chapter xvi. international, Article 1, 6-9-2012

8. Mai Ngoc Khuong and Dang Thuy Hoang, The Effects of Leadership Styles on Employee Motivation in Auditing Companies in Ho Chi Minh City, Vietnam, International Journal of Trade, Economics and Finance, Vol. 6, No. 4, August 2015

9. Osabiya Babatunde, Ikenga Emem, The Impact of Leadership Style on Employee's Performance in an Organization, Public Policy and Administration Research www.iiste.org, ISSN 2224-5731(Paper) ISSN 2225-0972(Online), Vol. 5, No. 1, 2015

10. Pennsylvania's Best Investment: The Social and Economic Benefits of Public Education, Pennsylvania's Best Investment: The Social and Economic Benefits of Public Education

11. Small and medium-sized enterprises and decent and productive employment creation, Report IV, ILO Geneva, International Labour Conference, 104th Session, 2015

12. Small and medium sized enterprises and decent and productive employment creation http://www.ioe-emp.org/index.php?eID=dumpFile \& $\mathrm{t}=\mathrm{f} \& \mathrm{f}=2506 \&$ token $=6 \mathrm{c} 418829 \mathrm{c} 0061 \mathrm{be} 076 \mathrm{aa} 2 \mathrm{fe} 19670 \mathrm{eeee} 66 \mathrm{cbde} 49$

13. The dynamic and importance of smes in economy, Maximilian ROBU, The USV Annals of Economics and Public Administration, Volume 13, Issue 1 (17), 2013

14. Quality of work life among it professionals in sme's in select cities of India Sulaksha Nayak, PhD research scholar and Senior lecturer, Department of Management studies, Manipal University, Dubai, United Arab Emirates Dr Harisha. G. Joshi, Associate Professor, Manipal Center of Information Science, Manipal University, India

15. http://www.ilo.org/wcmsp5/groups/public/@ed_norm/@relconf/documents/m eetingdocument/wcms_358294.pdf

16. https://ec.europa.eu/growth/sites/growth/files/docs/body/do-smes-create-moreand-better-jobs_en.pdf 